\title{
Proteinase activity in latex of three plants of the family Euphorbiaceae
}

\author{
Andréa Michel Sobottka ${ }^{1, *}$, Fabiana Tonial², Sonja Sytwala ${ }^{3}$, Matthias Melzig \\ ${ }^{1}$ School of Pharmacy, Institute of Biological Sciences, University of Passo Fundo, Rio Grande do Sul, Brazil, ${ }^{2}$ Department of \\ Basic Pathology, Section of Biological Sciences, Federal University of Paraná, Curitiba, Brazil, ${ }^{3}$ Institute of Pharmacy, Free \\ University of Berlin, Berlin, Germany
}

\begin{abstract}
In the family of Euphorbiaceae, the genera Euphorbia and Sapium are known to contain essentially latex-bearing species. In the present study, the latex of Euphorbia selloi (Klotzsch \& Garcke) Boiss., Euphorbia papillosa A.St.-Hil., and Sapium glandulosum (L.) Morong, plants native from Brazil, were examined concerning proteolytic activity. All studied species have proteins with significant proteolytic activity and E. papillosa has the greatest specific activity. Aiming to verify the type of protease present, an assay with different inhibitors was performed. In the three tested plants, the proteolytic activity was significantly inhibited by a serine protease inhibitor 4-(2-aminoethyl)-benzenesulfonyl fluoride hydrochloride (AEBSF). Using techniques of electrophoresis with polyacrylamide gels (SDS-PAGE), the subunits of proteins were separated according to their molecular masses, and the protein activity was visually detected by zymography.
\end{abstract}

Uniterms: Euphorbiaceae/species/phytochemistry. Euphorbia papillosa/phytochemistry. Euphorbia selloi/ phytochemistry. Sapium glandulosum/phytochemistry. Euphorbia papillosa/proteinase activity. Euphorbia selloi/proteinase activity. Sapium glandulosum/proteinase activity. Endopeptidase. Gel electrophoresis.

Dentro da família Euphorbiaceae, os gêneros Euphorbia e Sapium são conhecidos por incluírem basicamente espécies produtoras de látex. No presente estudo, o látex das plantas Euphorbia selloi (Klotzsch \& Garcke) Boiss., Euphorbia papillosa A.St.-Hil. e Sapium glandulosum (L.) Morong, espécies nativas do Brasil, foi analisado em relação à atividade proteolítica. Todas as amostras analisadas possuem proteínas com significativa atividade, sendo que o látex da espécie E. papillosa apresenta a maior atividade específica. Com o objetivo de analisar quais os tipos de proteases responsáveis pela atividade proteolítica, realizaram-se ensaios com diferentes inibidores. Nas três plantas testadas a atividade foi inibida significativamente pelo cloridrato de 4-(fluoreto de 2-aminoetilbenzenossulfonil) (AEBSF), um inibidor de serino-proteases. Utilizando técnicas de eletroforese em gel de poliacrilamida (SDS-PAGE), as subunidades das proteínas foram separadas de acordo com sua massa molecular e, através da zimografia, a atividade proteolítica pode ser detectada visualmente.

Unitermos: Euphorbiaceae/espécies/fitoquímica. Euphorbia papillosa/fitoquímica. Euphorbia selloi/ fitoquímica. Sapium glandulosum/fitoquímica. Euphorbia papillosa/atividade proteolítica. Euphorbia selloi/atividade proteolítica. Sapium glandulosum/atividade proteolítica. Endopeptidases. Eletroforese em gel.

\section{INTRODUCTION}

The Euphorbiaceae is one of the largest families of the angiosperms and the genus Euphorbia is the largest in this plant family, comprising about 2000 known species.

\footnotetext{
*Correspondence: A. M. Sobottka. Curso de Farmácia, Instituto de Ciências Biológicas, Universidade de Passo Fundo, Campus I - Rodovia BR 285 Km 292 - Bairro São José, 99.052-900 - Passo Fundo - RS, Brasil. E-mail: sobottka@upf.br
}

The genus Sapium also belongs to the Euphorbiaceae and about 120 species are distributed worldwide. Both genera are composed essentially of latex-bearing species, some of them used as medicinal agents (Ahmed et al., 2010; Baloch, Baloch, Baloch, 2010; Chaudhary et al., 2011; Kumar, Malhotra, Kumar, 2010; Sun, Liu, 2011).

The plants Euphorbia selloi (Klotzsch \& Garcke) Boiss., Euphorbia papillosa A.St.-Hil., and Sapium glandulosum (L.) Morong are latex-bearing species of Euphorbiaceae native from Brazil. E. papillosa and 
E. selloi are shrubs that occur in the southern region of Brazil. The roots of Euphorbia papillosa, commonly called "erva-leiteira", are used in Argentina as galactogogues (Martinez-Crovetto, 1981). Sapium glandulosum is a tree popularly known as "leiteiro" and is one of the Brazilian native species potentially recommended for the recovery of degraded areas (Ferreira et al., 2009).

Latex is a milky fluid found in the vacuole of secretory cells known as laticifers, which contain a complex mixture of constituents and various biochemical properties. Among the components various enzymes, terpenes, alkaloids, vitamins, carbohydrates, lipids, and free amino acids have been identified (Hagel, Yeung, Facchini, 2008; Lynn, Clevette-Radford, 1987). Many proteases from the latex of different species of Euphorbiaceae have been already reported (Lynn, Clevette-Radford, 1988).

The proteolytic enzymes found in the latex have received special attention because they remain active over a wide range of temperatures and $\mathrm{pH}$. Proteases represent ca. $60 \%$ of all commercialized enzymes in the world. The fields of applications include food science and technology, pharmaceutical industries, and detergent manufacturing. In the last few years, plant proteases have been the object of attention from the pharmaceutical industry and biotechnology (Domsalla, Görick, Melzig, 2010; FeijooSiota, Villa, 2011). Most of the proteolytic enzymes from the latex studied belong to the family of cysteine or serine endopeptidases and one is known to belong to the aspartic family (Domsalla, Melzig, 2008).

According to our knowledge, the chemical constituents of the E. papillosa and E. selloi have not been investigated so far. Regarding the species Sapium glandulosum, only one study that investigated the content of phenolic compounds and the antioxidant activity of ethanol extracts of the bark and leaves was found (Silva et al., 2011). The aim of this study was the investigation of the latex from plants of the family Euphorbiaceae concerning proteinase activity. The type of protease involved in the proteolytic activity was evaluated by testing the effect of different inhibitors. In addition, the subunits of proteins were visualized using techniques of electrophoresis.

\section{MATERIAL AND METHODS}

\section{Plant material}

The plant Euphorbia papillosa A.St.-Hil. was collected in Passo Fundo, Brazil, in geographic coordinates $28^{\circ} 13$ '59" S, 52 $22^{\prime} 48^{\prime \prime} \mathrm{W}$ and identified by Prof. Branca Maria Aimi Severo (RSPF 12647). A voucher was deposited in the Herbarium of the Universidade de Passo Fundo. Euphorbia selloi (Klotzsch \& Garcke) Boiss. and Sapium glandulosum (L.) Morong were collected in Guaíba, Brazil, at geographic coordinates $30^{\circ} 10^{\prime} 4$ " S and $51^{\circ} 23^{\prime} 3$ " W and identified by Prof. Dr. Mara Rejane Ritter. A voucher was deposited in the Herbarium of the Universidade Federal do Rio Grande do Sul (E. selloi ICN 151455; S. glandulosum ICN 164089). The plants were collected in December 2011. The crude latex of E. papillosa and S. glandulosum was extracted by cutting through the leaves and stem of the plants and then placed in glass tubes. The latex of E. selloi was also extracted by cutting the leaves and because of its small amount it was collected on a paper filter.

For the protein analysis, the latex of E. papillosa and $S$. glandulosum was lyophilized and the lyophilisate (or the paper filter, in the case of E. selloi) was placed in an Eppendorf tube, reconstituted with $500 \mu \mathrm{L}$ PBSbuffer (phosphate buffered saline, $\mathrm{pH}$ 7.2), submitted to sonification (Sonorex RK 100) for 15 min (to release all the proteins of the lyophilisate or attached to the paper filter) and to centrifugation $\left(4^{\circ} \mathrm{C}, 14000 \mathrm{rpm}, 60 \mathrm{~min}\right.$, Hettich Zentrifuge Micro200R). The supernatant was used for the assays.

\section{Protein content}

The protein measurement was performed with a BCA protein assay (Pierce Protein Research Products, Thermo Scientific, Rockford, USA), in which the bicinchoninic acid (BCA) was used as a protein detecting reagent (Smith et al., 1985; Wiechelman, Braun, Fitzpatrick, 1988). Samples $(25 \mu \mathrm{L}$ of the supernatant) were combined with BCA working reagent $(200 \mu \mathrm{L})$ and incubated at $37^{\circ} \mathrm{C}$ for $30 \mathrm{~min}$, into a 96 well microplate. The absorbances were measured at $560 \mathrm{~nm}$ against a blank (PBS + BCA reagent) plus a reagent blank ( $\mathrm{PBS}+$ sample) to eliminate possible interfering effects of the color (turbidity) of latex at the absorption determination. The protein content was determined from a plot of concentration vs. absorbances obtained with bovine serum albumin (BSA) standard. The values were expressed as mean values \pm SEM (Standard Error Mean).

\section{Proteolytic activity}

Protease activity was assayed using BODIPY ${ }^{\circledR}$ FL-casein as a substrate (Jones et al., 1997; Thompson et al., 2000). To $25 \mu \mathrm{L}$ of the supernatant were added $100 \mu \mathrm{L}$ of BODIPY ${ }^{\circledR}$ FL-casein (EnzChek ${ }^{\circledR}$ Protease Assay Kits green fluorescence, Invitrogen, Darmstadt, Germany) and incubated at $37^{\circ} \mathrm{C}$ for $60 \mathrm{~min}$, into a 96 
well microplate. The increase in fluorescence was detected in a microtiter plate fluorescence reader (Tecan infinite 200, Tecan Trading AG, Carlsheim) against a blank (PBS + BODIPY ${ }^{\circledR}$ FL-casein), with an excitation wavelength of $485 \mathrm{~nm}$ and an emission wavelength of $535 \mathrm{~nm}$, amplification 65 . The results obtained from each species were compared against the blank by using the MannWhitney test. In all comparisons, $\mathrm{p}<0.05$ was considered statistically significant. The values were expressed as mean values $\pm \mathrm{SEM}$.

\section{Residual activity with inhibitors}

To investigate the nature of endopeptidases, a set of specific inhibitors for serine- (AEBSF), cysteine(E64), aspartic- (Pepstatin A) and metalloprotease (EDTA) was proved. For AEBSF (4-(2-aminoethyl)benzenesulfonyl fluoride hydrochloride) an aqueous solution of concentration $10 \mathrm{mg} / \mathrm{mL}$ (Roche Applied Science) was used. For E64 ( $N$-(trans-epoxysuccinyl)L-leucine 4-guanidinobutylamide) an aqueous solution of $35 \mu \mathrm{g} / \mathrm{mL}$ (Barrett et al., 1982) was used. The analysis with pepstatin A (Isovaleryl-L-val-L-val-4-(S)-amino-3(S)-hydroxy-6-methyl-heptanoyl-2-ala-4-(S)-amino-3(S)- hydroxy-6-methyl-heptanoic acid) was performed in an a aqueous solution of concentration $2.45 \mu \mathrm{g} / \mathrm{mL}$ (Marciniszyn, Hartsuck, Tang, 1976) and with EDTA (ethylene diamine tetraacetic acid) in an a aqueous solution of $13.02 \mu \mathrm{g} / \mathrm{mL}$.

The latex samples ( $25 \mu \mathrm{L}$ of the supernatant) were gently swirled with $50 \mu \mathrm{L}$ of each type of inhibitor and pre-incubated for $30 \mathrm{~min}$ at $37^{\circ} \mathrm{C} .100 \mu \mathrm{L}$ of BODIPY ${ }^{\circledR}$ FL-casein were added. The samples were incubated again at $37^{\circ} \mathrm{C}$ for $60 \mathrm{~min}$ and the fluorescence was determined in a microtiter plate fluorescence reader, as previously described. The assay performed without any of the inhibitors served as initial reference activity $(100 \%)$ and the remaining activity was calculated as a percentage from this initial activity. The determination of the fluorescence was carried out at an excitation wavelength of $485 \mathrm{~nm}$ and an emission wavelength of $535 \mathrm{~nm}$, amplification 65 . The results obtained from each species in the presence of inhibitors were compared against the reference without inhibitors by using one-sample t-test. In all comparisons, $\mathrm{p}<0.05$ was considered statistically significant. The values were expressed as mean values \pm SEM.

\section{Electrophoresis SDS-PAGE}

Electrophoresis using polyacrylamide gels (SDS-PAGE) was performed as described by Laemmli
(1970), using 12\% gels. The lyophilized latex samples were prepared as previously described (suspended in PBS-buffer, submitted to sonification and centrifugation). The supernatant and standard were mixed with Laemmli sample buffer $(1: 1, \mathrm{v} / \mathrm{v})$, which was prepared prior to use (425 $\mu \mathrm{L}$ sample buffer $+25 \mu 12$-mercaptoethanol). After agitation, samples and standard were heated at $95^{\circ} \mathrm{C}$ for 5 min (Thermocycler RK13 HLC) and applied to gel (samples in duplicate). Electrophoresis was carried out at $200 \mathrm{~V}(35 \mathrm{~mA}-20 \mathrm{~mA} ; 40 \mathrm{~min})$ and at a temperature between $4-10{ }^{\circ} \mathrm{C}$. After electrophoresis, gels were fixed in a solution of $40 \%$ methanol and $10 \%$ acetic acid (overnight). One gel was stained with silver and another with Coomassie blue.

\section{Zymography}

For the zymogram analysis, the lyophilized latex samples were prepared as previously described (suspended in PBS-buffer, submitted to sonification and centrifugation). The supernatant was mixed $(1: 1, \mathrm{v} / \mathrm{v})$ with zymogram sample buffer (62.5\% Tris- $\mathrm{HCl} \mathrm{pH} 6.8$; 4\% SDS; $25 \%$ glycerol; $0.01 \%$ bromphenolblue, Bio Rad, Munich) and applied in duplicate to the gel (Ready gel zymogram precast-gel, 12.5\% Zymogram casein, Bio Rad, Munich). The analysis was carried out at $100 \mathrm{~V}(27 \mathrm{~mA}$ $08 \mathrm{~mA} ; 110 \mathrm{~min}$ ) and at a temperature between $4-10{ }^{\circ} \mathrm{C}$. Renaturation was performed with $2.5 \%$ Triton X-100 for $30 \mathrm{~min}$. Hereafter the gel was incubated overnight at $37^{\circ} \mathrm{C}$ with $50 \mathrm{mM}$ Tris; $200 \mathrm{mM} \mathrm{NaCl} ; 5 \mathrm{mM} \mathrm{CaCl}$; $0.02 \%$ Brij-35. The staining was performed for $1 \mathrm{~h}$ at room temperature with Coomassie-Brilliant blue R-250 and destaining with $40 \%$ methanol and $10 \%$ acetic acid.

\section{RESULTS AND DISCUSSION}

The protein-content data, proteolytic activity, and specific activity from the three tested species are shown in Table I. All plants demonstrated significant proteolytic activity in the latex. Particularly the latex of E. papillosa, with low protein content, showed a strong proteolytic activity, and the greatest specific activity.

To elucidate the nature of proteolytic activity, a set of inhibitors for different types of proteases was studied. As presented in Table II, in E. papillosa, the activity was strongly inhibited by a serine protease inhibitor (AEBSF), but not by pepstatin, EDTA or cysteine protease inhibitors (E64), indicating that the enzyme present in the latex of this plant depends on a serine residue for catalytic activity. The results for $E$. sello $i$ also showed a statistically significant reduction of protease 
activity by a serine protease inhibitor, while the aspartic protease inhibitor (Pepstatin A) had the opposite effect, thus increasing the enzymatic activity. In the species $S$. glandulosum, the activity of the enzyme was strongly inhibited by a cysteine protease inhibitor (E64) and weakly by serine and aspartic inhibitors. In the three plants tested, the proteolytic activity was significantly inhibited by serine protease inhibitor. For years, it was believed that serine proteases were rare in plants, but recently, several proteolytic enzymes that depend on a serine residue for catalytic activity have been isolated from various plant species with distinct locations, ranging from seeds to latex or fruits (Feijoo-Siota, Villa, 2011). In latex, the majority of proteases with considerable commercial importance are from cysteine type, such as papain, which is one of the most studied peptidases and is commercially available (El Moussaoui et al., 2001). Also, the latex of Calotropis procera has two known cysteine proteases (procerain and procerain B) and recently a new enzyme was purified from this latex (Ramos et al., 2013). However, serine proteases are found in the latex of Euphorbiaceae. This type of enzyme was obtained, for example, from the latex of Euphorbia supina (Arima et al., 2000) and Euphorbia milii, with potential applications in food industry (Yadav, Pande, Jagannadham, 2006; Moro et al., 2008; Fonseca et al., 2010). Also from Euphorbia hirta, a serine protease, with fibrinolytic activity and potential industrial and therapeutic applications, was purified (Patel, Kawale,
Sharma, 2012). Antão and Malcata (2005) reviewed this class of enzymes, which also showed their mechanism of action.

SDS-PAGE was performed and, for the three samples, a variety of protein bands of different intensities and molecular masses were detected, both in the silver stained gel (Figure 1A) and in the Coomassie blue stained gel (Figure 1B). All applied samples showed some characteristic bands of proteins with molecular mass between $31-45 \mathrm{kDa}$, with at a least one protein of the same molecular mass in the three samples. The sample $S$. glandulosum showed a characteristic protein band with a molecular mass corresponding to BSA standard. The other two samples applied, E. papillosa and E. selloi, showed a high intensity band just above of BSA standard. This characteristic band is likely the same protein in the two samples and can be visualized by silver and Coomassie stain. For the sample E. selloi (and E. papillosa, detected by Coomassie), a characteristic protein band, with molecular mass corresponding to ovalbumin standard, was also detected. This band can be better visualized by silver stain and seems to be also present in the sample of S. glandulosum, but with a weak staining. In all samples, a protein band at the top of the gel was detectable, which shows a molecular mass greater than of $200 \mathrm{kDa}$. Similarly, for all the samples, a characteristic band in the lower area of the gel, corresponding to aprotinin standard, was detected. For the samples E. papillosa and E. selloi, it was also possible to visualize protein bands in the same

TABLE I - Protein content, proteolytic activity and specific activity from the latex of E. selloi, E. papillosa and S. glandulosum

\begin{tabular}{lccc}
\hline & $\begin{array}{c}\text { Protein content } \\
\left(\mu \mathrm{g} \cdot \mathrm{mL}^{-1}\right)(\mathrm{n}=6) \\
\text { Mean } \pm \text { SEM }\end{array}$ & $\begin{array}{c}\text { Proteolytic activity }(\mathrm{n}=24) \\
\text { Mean } \pm \text { SEM }\end{array}$ & $\begin{array}{c}\text { Specific activity } \\
\left(\mathrm{U}_{\mu} \mu \mathrm{g}^{-1}\right)\end{array}$ \\
\hline Euphorbia selloi & $791 \pm 26,8$ & $2005^{*} \pm 91$ & 2.5 \\
Euphorbia papillosa & $167 \pm 15,7$ & $16497^{*} \pm 320$ & 98.8 \\
Sapium glandulosum & $888 \pm 113,8$ & $5489^{*} \pm 140$ & 6.2 \\
\hline
\end{tabular}

* significant difference to the control (Mann-Whitney test); $\mathrm{p}<0.05$

TABLE II - Residual activity of proteases from the latex after treatment with selected inhibitors

\begin{tabular}{lccc}
\hline Inhibitor & $\begin{array}{c}\text { E. selloi } \\
\text { Mean }(\%) \pm \text { SEM }\end{array}$ & $\begin{array}{c}\text { E. papillosa } \\
\text { Mean }(\%) \pm \text { SEM }\end{array}$ & $\begin{array}{c}\text { S. glandulosum } \\
\text { Mean }(\%) \pm \text { SEM }\end{array}$ \\
\hline AEBSF & $61.9^{*} \pm 5.01$ & $15.8^{*} \pm 0.50$ & $49.8^{*} \pm 2.38$ \\
E64 & $95.6 \pm 5.01$ & $105.5^{*} \pm 1.19$ & $21.4^{*} \pm 1.14$ \\
Pepstatin A & $170.2^{*} \pm 5.65$ & $111.4^{*} \pm 2.82$ & $65^{*} \pm 4.66$ \\
EDTA & $111.3 \pm 5.46$ & $110^{*} \pm 2.01$ & $111^{*} \pm 2.86$ \\
\hline
\end{tabular}

$\%$ - Mean of residual activity $(\mathrm{n}=12) ; *$ significant difference to the control (t-test); $\mathrm{p}<0.05$ 


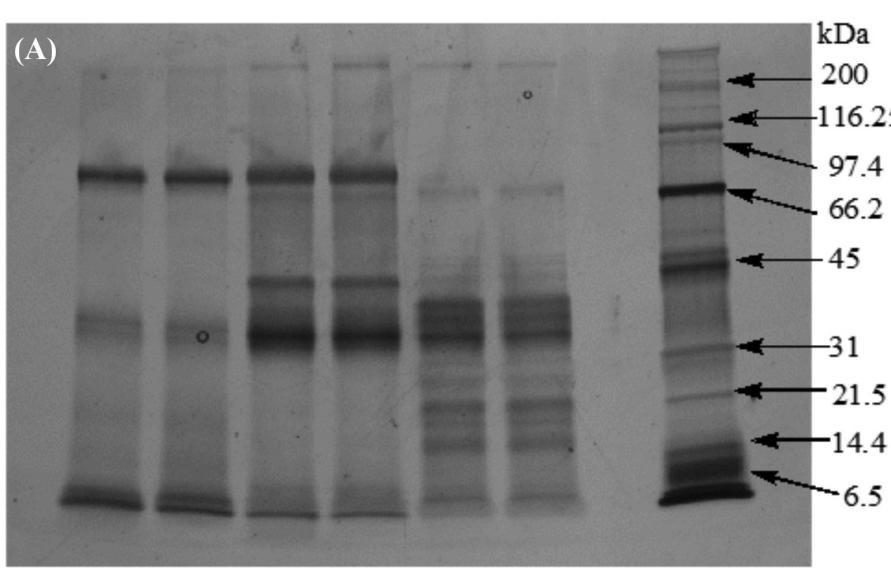

E. papillosa

E. selloi S. glandulosum

Standard

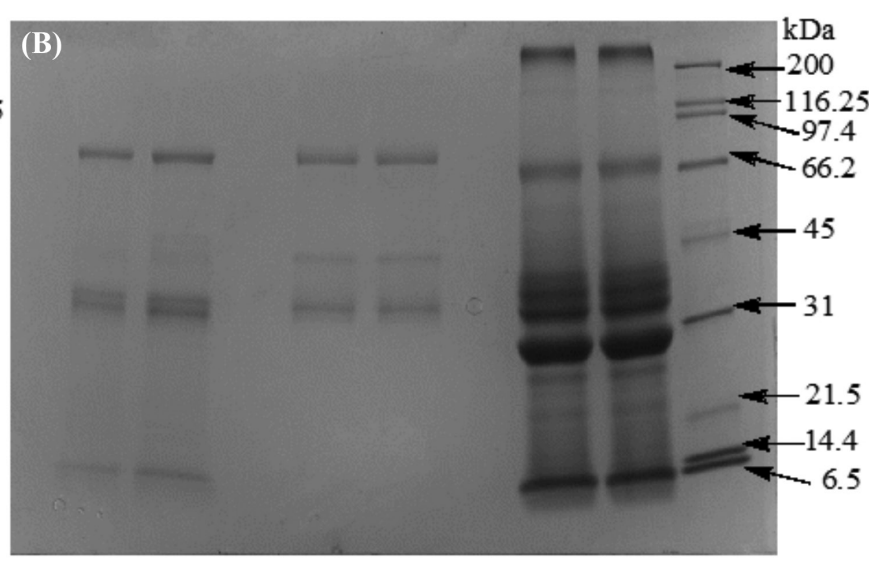

E. papillosa
E. selloi
S. glandulosum Standard

FIGURE 1 - SDS-PAGE gel electrophoresis from the latex of E. papillosa, E. selloi, S. glandulosum and from standard. (A): stained with silver; (B): stained with Coomassie blue.

lower area of the gel, but these bands were detected by silver and not by Coomassie stain.

$20 \mu \mathrm{L}$ of samples (in duplicate) and $10 \mu \mathrm{L}$ of standard were applied into each gel slot.

The (standard) molecular mass markers used were: Myosin (200 kDa), beta-galactosidase (116.25 kDa), phosphorylase B (97.4 kDa), bovine serum albumin (66.2 $\mathrm{kDa})$, ovalbumin (45 kDa), carbonic anhydrase (31 kDa), soybean trypsin inhibitor $(21.5 \mathrm{kDa})$, lysozyme (14.4 kDa) and aprotinin $(6.5 \mathrm{kDa})$.

In order to provide a visual detection of the protein activity, zymography was performed (FernándezResa, Mira, Quesada, 1995; Wilkesman, Kurz, 2009). In Figure 2, the E. papillosa sample shows a strong degradation of casein in the upper area of the gel. This major degradation appears to correspond to a protein band, but it is also possible that it corresponds to two or more proteins with proteolytic activity. The results confirmed the strong proteolytic activity from the latex of E. papillosa found by direct fluorescence measurement. For the sample of E. selloi, the zymogram showed a similar profile. In this case, the major degradation of casein appears to correspond to two proteins. However, it was not possible to obtain the bands clearly resolved, even when repeating the zymogram with different sample concentrations. These results confirmed the presence of proteins with proteolytic activity in the latex from E. selloi. For the sample of Sapium glandulosum degradation of casein was not visualized even at a higher sample concentration. In this case, a small degradation of casein was seen in the upper area of the gel.

The antimicrobial activity of the latex of E. papillosa and $S$. glandulosum was tested against Alternaria sp. and Fusarium graminearum by mycelial inhibition, and

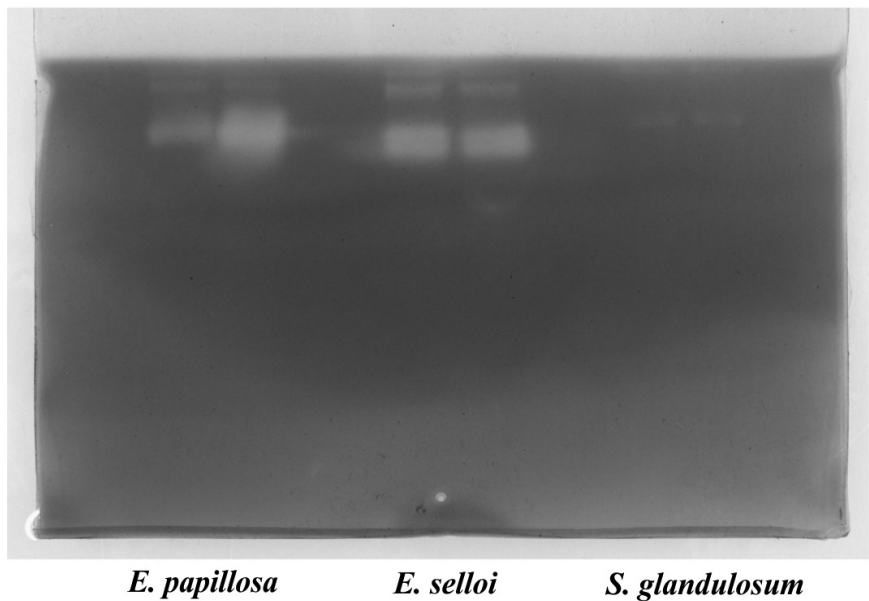

FIGURE 2 - Zymography gel electrophoresis from the latex of $E$. papillosa, E. selloi and S. glandulosum stained with Coomassie blue and using casein as a protein substrate.

Candida albicans (ATCC 10231), Escherichia coli (ATCC 35219), Salmonella typhi (ATCC 19196), Staphylococcus aureus (ATCC 27213) and Bacillus cereus by broth microdilution (data not shown). No relevant activity was detected. The most promising result was a MIC of $15 \mathrm{mg} / \mathrm{mL}$ of E. papillosa extract against $C$. albicans.

\section{CONCLUSION}

The present study showed that the latex from Euphorbia papillosa, Euphorbia selloi and Sapium glandulosum has proteins with significant proteolytic activity and this activity is significantly inhibited by a serine protease inhibitor. By SDS-PAGE electrophoresis, all samples showed some characteristic bands of proteins, highlighting the bands with a molecular 
weight corresponding to ovalbumin, aprotinin, and BSA standards. The bands from ovalbumin and aprotinin seem to be present in all samples, and the band corresponding to BSA standard is clearly present in the sample from Sapium glandulosum. It is interesting to highlight that the two plants of the genus Euphorbia showed a similar profile.

\section{ACKNOWLEDGEMENTS}

The authors would like to thank Dr. Nelson Ivo Matzenbacher, Dr. Mara Rejane Ritter and MSc. Branca Maria Aimi Severo for the assistance in the collection and botanical identification of plant material.

\section{REFERENCES}

AHMED, Y.; SOHRAB, M.H.; AL-REZA, S.M.; TAREQ, F.S.; HASAN, C.M.; SATTAR, M.A. Antimicrobial and cytotoxic constituents from leaves of Sapium baccatum. Food Chem. Toxicol., v.48, n.2, p.549-552, 2010.

ANTÃO, C.M.; MALCATA, F.X. Plant serine proteases: biochemical, physiological and molecular features. Plant Physiol. Biochem., v.43, n.7, p.637-650, 2005.

ARIMA, K.; UCHIKOBA, T.; YONEZAWA, H.; SHIMADA, M.; KANEDA, M. Cucumisin-like protease from the latex of Euphorbia supina. Phytochemistry, v.53, n.6, p.639-644, 2000.

BALOCH, I.B.; BALOCH, M.K.; BALOCH, A.K. Schistosomiasis suppressing deoxyphorbol esters from Euphorbia cauducifolia L. latex. Planta Med., v.76, n.8, p.809-814, 2010.

BARRETT, A.J.; KEMBHAVI, A.A.; BROWN, M.A.; KIRSCHKE, H.; KNIGHT, C.G.; TAMAI, M.; HANADA, K. L-trans-Epoxysuccinyl-leucylamido(4-guanidino) butane (E-64) and its analogues as inhibitors of cysteine proteinases including cathepsins B, H and L. Biochem. J., v.201, n.1, p.189-198, 1982.

CHAUDHARY, H.J.; ZEB, A.; BANO, A.; RASUL, F.; MUNIS, M.F.H.; FAHAD, S.; NASEEM, W. Antimicrobial activities of Sapium sebiferum L. belonging to family Euphorbiaceae. J. Med. Plants Res., v.5, n.24, p.5916-5919, 2011.

DOMSALLA, A.; MELZIG, M.F. Occurrence and properties of proteases in plant latices. Planta Med., v.74, n.7, p.699$711,2008$.
DOMSALLA, A.; GÖRICK, C.; MELZIG, M.F. Proteolytic activity in latex of the genus Euphorbia - a chemotaxonomic marker? Pharmazie, v.65, n.3, p.227-230, 2010.

EL MOUSSAOUI, A.; NIJS, M.; PAUL, C.; WINTJENS, R.; VINCENTELLI, J.; AZARKAN, M.; LOOZE, Y. Revisiting the enzymes stored in the laticifers of Carica papaya in the context of their possible participation in the plant defence mechanism. Cell Mol. Life Sci., v.58, n.4, p.556-570, 2001.

FEIJOO-SIOTA, L.; VILLA, T.G. Native and biotechnologically engineered plant proteases with industrial applications. Food Bioprocess Technol., v.4, n.6, p.1066-1088, 2011.

FERNÁNDEZ-RESA, P.; MIRA, E.; QUESADA, A.R. Enhanced detection of casein zymography of matrix metalloproteinases. Anal. Biochem., v.224, n.1, p.434-435, 1995.

FERREIRA, B.G.A.; ZUFFELLATO-RIBAS, K.C.; CARPANEZZI, A.A.; TAVARES, F.R.; KOEHLER, H.S. Methodologies of IBA application in the rooting of Sapium glandulatum (Vell.) Pax semi-hardwood cuttings. Rev. Bras. Plantas Med., v.11, n.2, p.196-201, 2009.

FONSECA, K.C.; MORAIS, N.C.G.; QUEIROZ, M.R.; SILVA, M.C.; GOMES, M.S.; COSTA, J.O.; MAMEDE, C.C.N.; TORRES, F.S.; PENHA-SILVA, N.; BELETTI, M.E.; CANABRAVA, H.A.N.; OLIVEIRA, F. Purification and biochemical characterization of Eumiliin from Euphorbia milii var. hislopii latex. Phytochemistry, v.71, n.7, p.708$715,2010$.

HAGEL, J.M.; YEUNG, E.C.; FACCHINI, P.J. Got milk? The secret life of laticifers. Trends Plant Sci., v.13, n.12, p.631639, 2008.

JONES, L.J.; UPSON, R.H.; HAUGLAND, R.P.; PANCHUKVOLOSHINA, N.; ZHOU, M.; HAUGLAND, R.P. Quenched BODIPY dye-labeled casein substrates for the assay of protease activity by direct fluorescence measurement. Anal. Biochem., v.251, n.2, p.144-152, 1997.

KUMAR, S.; MALHOTRA, R.; KUMAR, D. Euphorbia hirta: its chemistry, traditional and medicinal uses, and pharmacological activities. Pharmacogn. Rev., v.4, n.7, p.58-61, 2010.

LAEMMLI, U.K. Cleavage of structural proteins during the assembly of the head of bacteriophage T4. Nature, v.227, n.5259, p.680-685, 1970. 
LYNN, K.R.; CLEVETTE-RADFORD, N.A. Biochemical properties of latices from the Euphorbiaceae. Phytochemistry, v.26, n.4, p.939-944, 1987.

LYNN, K.R.; CLEVETTE-RADFORD, N.A. Proteases of Euphorbiaceae. Phytochemistry, v.27, n.1, p.45-50, 1988.

MARCINISZYN JR., J.; HARTSUCK, J.A.; TANG, J. Mode of inhibition of acid proteases by pepstatin. J. Biol. Chem., v.251, n.22, p.7088-7094, 1976.

MARTINEZ-CROVETTO, R. Las plantas utilizadas en medicina popular en el noroeste de Corrientes (Republica Argentina). Miscelanea v.69. Fundación Miguel Lillo, 1981. $139 \mathrm{p}$.

MORO, L.P.; MURAKAMI, M.T.; CABRAL, H.; VIDOTTO, A.; TAJARA, E.H.; ARNI, R.K.; JULIANO, L.; BONILLARODRIGUEZ, G.O. Purification, biochemical and functional characterization of miliin, a new thiol-dependent serine protease isolated from the latex of Euphorbia milii. Protein Pept. Lett., v.15, n.7, p.724-730, 2008.

PATEL, G.K.; KAWALE, A.A.; SHARMA, A.K. Purification and physicochemical characterization of a serine protease with fibrinolytic activity from latex of a medicinal herb Euphorbia hirta. Plant Physiol. Biochem., v.52, p.104-111, 2012.

RAMOS, M.V.; ARAÚJO, E.S.; JUCÁ, T.L.; MONTEIROMOREIRA, A.C.O.; VASCONCELOS, I.M.; MOREIRA, R.A.; VIANA, C.A.; BELTRAMINI, L.M.; PEREIRA, D.A.; MORENO, F.B. New insights into the complex mixture of latex cysteine peptidases in Calotropis procera. Int. J. Biol. Macromol., v.58, p.211-219, 2013.
SILVA, C.H.T.P.; PEIXOTO SOBRINHO, T.J.S.; CASTRO, V.T.N.A.; LIMA, D.C.A.; AMORIM, E.L.C. Antioxidant capacity and phenolic content of Caesalpinia pyramidalis Tul. and Sapium glandulosum (L.) Morong from northeastern Brazil. Molecules, v.16, n.6, p.4728-4739, 2011.

SMITH, P.K.; KROHN, R.I.; HERMANSON, G.T.; MALLIA, A.K.; GARTNER, F.H.; PROVENZANO, M.D.; FUJIMOTO, E.K.; GOEKE, N.M.; OLSON, B.J.; KLENK, D.C. Measurement of protein using bicinchoninic acid. Anal. Biochem., v.150, n.1, p.76-85, 1985.

SUN, Y.X.; LIU, J.C. Chemical constituents and biological activities of Euphorbia fischeriana steud. Chem. Biodivers., v.8, n.7, p.1205-1214, 2011.

THOMPSON, V.F.; SALDAÑA, S.; CONG, J.; GOLL, D.E. A BODIPY fluorescent microplate assay for measuring activity of calpains and other proteases. Anal. Biochem., v.279, n.2, p.170-178, 2000.

WIECHELMAN, K.J.; BRAUN, R.D.; FITZPATRICK, J.D. Investigation of the bicinchoninic acid protein assay: identification of the groups responsible for color formation. Anal. Biochem., v.175, n.1, p.231-237, 1988.

WILKESMAN, J.; KURZ, L. Protease analysis by zymography: a review on techniques and patents. Recent. Pat. Biotechnol., v.3, n.3, p.175-184, 2009.

YADAV, S.C.; PANDE, M.; JAGANNADHAM, M.V. Highly stable glycosylated serine protease from the medicinal plant Euphorbia milii. Phytochemistry, v.67, n.14, p.1414-1426, 2006.

Received for publication on $19^{\text {th }}$ July 2013 Accepted for publication on $14^{\text {th }}$ January 2014 
